\title{
3 Research Square

\section{Hematological profile of children under five years with typhoid fever at Idaman Banjarbaru Hospital, Indonesia}

Harapan Parlindungan Ringoringo ( $\sim$ parlinringoringo@ulm.ac.id)

Faculty Of Medicine Of Lambung Mangkurat University

Indah Indriyah Wahyuni

Faculty Of Medicine Of Lambung Mangkurat University

Roselina Panghiyangani

Faculty Of Medicine Of Lambung Mangkurat University

Edi Hartoyo

Faculty Of Medicine Of Lambung Mangkurat University

Rahmiati Lao

Faculty Of Medicine Of Lambung Mangkurat University

\section{Research Article}

Keywords: typhoid fever, under-five child, hematological profile.

Posted Date: May 21st, 2021

DOI: https://doi.org/10.21203/rs.3.rs-524279/v1

License: (c) (1) This work is licensed under a Creative Commons Attribution 4.0 International License. Read Full License 


\section{Abstract}

Introduction: Typhoid fever is a disease caused by Salmonella typhi, Salmonella paratyphi A, B, C. An estimated 200,000 people die each year from about 21.6 million people infected with typhoid fever. This study aims to determine the hematological profile in typhoid fever cases in children under five at Idaman Banjarbaru Hospital.

Methods: The research was carried out with a retrospective descriptive approach with a consecutive sampling technique. The research subjects were children under five diagnosed with typhoid fever recorded in the RSD Idaman Banjarbaru's medical records for July 2018 to January 2019.

Results: The sample consisted of 58 patients, 32 boys, and 26 girls. Most patients were found in $12-<36$ months, namely 28 (48.28\%) children. Thirty-eight (65.52\%) children have a normal weight. The hematological profile showed that $46.55 \%$ of the patients had iron deficiency anemia (IDA). Hematocrit levels decreased in $51.72 \%$ of patients. Erythrocyte levels in $86.21 \%$ of patients were normal. Low MCV, low $\mathrm{MCH}$, IDA were found in $46.55 \%, 36.21 \%, 46.55 \%$ of patients. Leukopenia was present in $17.24 \%$ of children. All patients had normal basophil values. Eosinopenia, band neutropenia, segmented neutropenia, lymphocytosis, monocytosis were found in $69.09 \%, 90.90 \%, 56.37 \%, 58.18 \%, 58.18 \%$ of children, respectively.

Conclusion: This study shows that $46.55 \%$ of children under five with typhoid fever suffer from IDA. In addition, Eosinopenia and band neutropenia were found in $69.09 \%, 90.90 \%$ of children, respectively.

\section{Introduction}

Typhoid fever is a disease caused by Salmonella typhi, Salmonella paratyphi A, B, and C. This disease is commonly found in children, especially in tropical countries [1]. Typhoid and paratyphoid fever are acute and often life-threatening febrile illnesses caused by systemic infection with the bacterium Salmonella enterica serotype typhi and paratyphi, respectively [A].

It is estimated that 200,000 people die each year out of the approximately 21.6 million people infected with typhoid fever. Central Asia, South Asia, Southeast Asia, and South Africa have an incidence of $>100$ cases per 100,000 population per year and are classified as countries with a high incidence of typhoid fever [2].

Typhoid fever has a clinical picture that varies widely from mild to severe, even with complications. The study at Department of Child Health Dr. Hasan Sadikin General Hospital, Bandung showed leucopenia at admission (42.1\%), and thrombocytopenia at admission (51.3\%)[B].

The aim of this study was to determine the hematological profile of children under five with typhoid fever. The results are expected to help diagnose typhoid fever so that the management of typhoid fever will be better and more focused. 


\section{Methods}

The research was carried out with a retrospective descriptive approach with a consecutive sampling technique. The research subjects were children under five diagnosed with typhoid fever recorded in the RSD Idaman Banjarbaru's medical records for July 2018 to January 2019. The inclusion criteria were children under five with typhoid fever. In addition, the parents agreed to the informed consent and permitted their child to have a complete blood count, Widal or IgM Salmonella typhy (Tubex test). The exclusion criteria were incomplete data from laboratory tests on medical records. All data were analyzed descriptively. Nutritional status is assessed based on body weight-for-age, divided into normal-weight and under-weight [4]. In this study, normal-weight if the z-score of -2 SD to +1 SD. The Under-weight if the zscore -3 SD $<z<-2$ SD. This study has obtained ethical clearance from the Research Ethics Commission of Medical Faculty of University of Lambung Mangkurat No. 297 // KEPM-FK UNLAM / EC / IX2020. The committee had approved the research, confirm that all research was performed following relevant guidelines/regulations.

\section{Results}

There were 58 children under five diagnosed with typhoid fever in this study, 32 boys and 26 girls.. Patient characteristics can be seen in Table-1.

Table-1. Characteristics of children under five with typhoid fever at the Idaman Banjarbaru Hospital for the period July 2018 - January 2019

\begin{tabular}{lcc}
\hline Characteristics $(\mathrm{n}=58)$ & Sum $(\mathrm{n})$ & $(\%)$ \\
\hline Age (Months) & \multicolumn{2}{c}{$13,79 \%$} \\
$6-<12$ & 28 & $48,28 \%$ \\
$12-<36$ & 22 & $37,93 \%$ \\
\hline $36-<60$ & $30,50 \pm 16,30$ \\
\hline Mean \pm SD & & \\
\hline Gender & 32 & $55,17 \%$ \\
\hline Boys & 26 & $44,83 \%$ \\
\hline Girls & & \\
\hline Nutritional status (Weight-for-age) & & \\
\hline$\quad$ Under-Weight & 20 & $34,48 \%$ \\
\hline$\quad$ Normal-Weight & 38 & $65,52 \%$ \\
\hline
\end{tabular}

Table-1 shows that most patients were found in $12-<36$ months, namely $28(48.28 \%)$ children. Thirtyeight $(65.52 \%)$ children have a normal weight.

Table-2 Hematological profile of children under five with typhoid fever based on erythrocyte index 


\begin{tabular}{llll}
\hline Hematological profile & $<$ Normal & Normal & $>$ Normal \\
\hline Hemoglobin & $27(46,55 \%)$ & $31(53,45 \%)$ & - \\
Hematocrit & $30(51,72 \%)$ & $28(48,28 \%)$ & $0(0,00 \%)$ \\
RBC $^{\mathrm{a}}$ & $7(12,07 \%)$ & $50(86,21 \%)$ & $1(1,72 \%)$ \\
MCV $^{b}$ & $27(46,55 \%)$ & $31(53,45 \%)$ & $0(0.00 \%)$ \\
MCH $^{\mathrm{C}}$ & $21(36,21 \%)$ & $36(62,07 \%)$ & $1(1,72 \%)$ \\
MCHC $^{d}$ & $1(1,72 \%)$ & $56(96,56 \%)$ & $1(1,72 \%)$ \\
RDWe & $0(0,00 \%)$ & $23(85,19 \%)$ & $4(14,81 \%)$ \\
Mentzer Index & $0(0,00 \%)$ & - & $27(100,0 \%)$ \\
RDW Index & $3(11,11 \%)$ & - & $24(88,89 \%)$ \\
\hline
\end{tabular}

Table-3 Hematological profile of children under five with typhoid fever based on leukocytes and leukocyte count

\begin{tabular}{llll}
\hline Hematological profile & $<$ Normal & Normal & $>$ Normal \\
\hline Leukocyte & $10(17,24 \%)$ & $41(70,69 \%)$ & $7(12,07 \%)$ \\
Basophils & $0(0,00 \%)$ & $55(100,00 \%)$ & $0(0,00 \%)$ \\
Eosinophils & $38(69,09 \%)$ & $15(27,27 \%)$ & $2(3,64 \%)$ \\
Band Neutrophils & $50(90,91 \%)$ & $5(9,09 \%)$ & $0(0,00 \%)$ \\
Segmented Neutrophils & $31(56,37 \%)$ & $3(5,45 \%)$ & $21(38,18 \%)$ \\
Lymphocyte & $19(34,55 \%)$ & $4(7,27 \%)$ & $32(58,18 \%)$ \\
Monocyte & $3(5,46 \%)$ & $20(36,36 \%)$ & $32(58,18 \%)$ \\
\hline
\end{tabular}

Tables-2 and Table-3 show the hematological profiles of typhoid fever patients in children under five based on erythrocyte index, leucocytes, and leukocyte count. Low MCV (microcytic) and low MCH (hypochromic) were found in $46.55 \%$ and $36.21 \%$ of patients.

\section{Discussion}

Based on Table-1, the highest age group was in the age group $12-<36$ months with a percentage of $48.28 \%$. This may be because, at that age, the children's hygiene habits are still lacking, and the children already have the desire to buy snacks at street vendors [5]. Inadequate hygienic habits were associated with carriers of bacterial enteric pathogens in families with children who had typhoid fever [6].

Salmonellae on the hands of convalescent carriers are easily removed by washing hands with soap and water [7]. In contrast to Setiabudi et al.'s research, it was found that the highest percentage was found in children under five years of age with a percentage of $65.8 \%$ [8].

Based on gender, it appears that typhoid fever was more prevalent in male children under five, namely 32 (55.17\%) children; this can happen because the boys are more active outside the house [9].

According to nutritional status, it appears that most children have normal body weight, namely $65.52 \%$. This study's results are different from Ramaningrum research that shows children with poor nutritional 
status will be more at risk of suffering from typhoid fever due to decreased immune systems [10].

Based on Table-2, it appears that 27 (46.55\%) children suffer from anemia. Based on the RDW value, the Mentzer index (MCV: RBC), and the RDW index (MCV: RBCxRDW), all 27 children suffering from anemia had IDA. The Mentzer Index and RDW index are used as IDA indicators [11]. If the Mentzer index value is $<13$, anemia is suspected due to minor thalassemia. If the Mentzer index value is $\geq 13$, then the anemia may be due to iron deficiency. RDW index value $\geq 220$ indicates anemia caused by iron deficiency [11]. The results of this study are different from the research by Lestari et al., which found that out of 158 children with typhoid fever, 116 (73.4\%) children had normal hemoglobin levels [12]. Low serum iron concentrations characterize anemia caused by inflammation (including typhoid fever); due to inhibited iron absorption because hepcidin degrades ferroportin, resulting in iron accumulation in intra-enterocyte cells [13-15].

Based on Table-3, it was found that leukopenia was found in 10 (17.24\%) patients. Leukopenia is associated with fever and disease toxicity. ${ }^{1}$ Qamar found 78 patients (52\%) had leukopenia [16]. Leukopenia occurs because patients infected with $S$. typhi bacteria secrete endotoxin on the germ's outer wall in the form of lipopolysaccharide to stimulate activated macrophages and phagocyte leukocytes and function to activate neutrophils. Also, leukopenia results from depression of the bone marrow by the endotoxins and endogenous mediators present $[16,17]$.

On the leukocyte count, all patients had normal basophil values. Eosinopenia was found in 38 (69.09\%) pediatric patients. Ishaq et al. study (2020) found that $59 \%$ of typhoid fever patients experience eosinopenia [18]. Eosinophils are active primarily in the late stages of inflammation when antigenantibody complexes are formed and have the ability to phagocytose $[19,20]$. Eosinopenia is usually associated with the presence of an acute bacterial infection that usually causes fever. The decrease of eosinophils is caused by the release of cytokines during margination that occurs in eosinophils [18].

Band neutropenia was seen in 50 (90.90\%) children and segmented neutropenia in 31 (56.37\%) children. Neutropenia is caused by decreased neutrophil production, increased cell damage, bacterial and viral infections, drugs, administration of chemotherapy, and autoimmune diseases $[19,20]$. This is suits with the study of Qamar et al. (2013) and Uplaonkar, which found neutropenia in 48 (32\%) typhoid fever patients [21,22].

Lymphocytosis was found in $58.18 \%$ of children. Relative lymphocytosis followed by neutropenia during the recovery phase is considered a feature of complications of typhoid fever [23]. Monocytosis was found in $58.18 \%$ of pediatric patients. This study's results are the same as that of Qamar et al. (2013), who found monocytosis in $30.67 \%$ of typhoid fever patients [22]. Monocytes are the largest blood cells and have a function as the body's second layer of defense and can perform phagocytosis properly and include macrophages. In the blood, monocytes will go to the source of inflammation to assist the host immune response and act as mediators of antimicrobial defense. Monocytosis is usually caused by infection with viruses, bacteria, parasites, autoimmune diseases [24]. 
In this study, thrombocytopenia and thrombocytosis were found in the same percentage, namely $13.80 \%$ of children. In Ahmad et al. study, they found thrombocytopenia in 127 (63,5\%\%) patients [25].

Thrombocytopenia is an essential marker in children presenting with typhoid fever, especially in those having severe symptoms. So platelet count should be monitored in patients with enteric fever. Because severe thrombocytopenia can lead to multi-organ failure and can considerably lead to increased morbidity and mortality [15].

\section{Conclusion}

This study shows that $46.55 \%$ of children under five with typhoid fever suffer from IDA. In addition, Eosinopenia and band neutropenia were found in $69.09 \%, 90.90 \%$ of children, respectively. The hematological profile of typhoid fever patients in children under five can have different results depending on each child's body's response to S. typhi and S. paratyphi that enter the body. The bacterial virulence, the patient's immune status, the previous vaccination against typhoid fever, and resistance to antibiotics can affect hematological profile changes [12,15].

\section{Declarations}

\section{Data Availability :}

The raw data of this research can be seen in this link https://drive.google.com/file/d/1YkAj9UqPNxPWx3rJzJNpcS6uFuyABf7l/view?usp=sharing

\section{Conflict of interest :}

The authors have no conflicts of interest to declare that are relevant to the content of this article.

\section{Funding:}

The authors did not receive any grant or funding.

\section{Acknowledgment:}

We want to thank nurse Novie Norhayati for collecting patient medical record data at RSD Idaman Banjarbaru.

\section{References}

1. Buckle GC, Walker CL, Black RE. Typhoid fever and paratyphoid fever: Systematic review to estimate global morbidity and mortality for 2010. J Glob Health 2012; 2:010401.

2. Paul UK, Bandyopadhyay A. Typhoid fever: a review. Int J Adv Med. 2017;4(2):300. doi:10.18203/2349-3933.ijam20171035 
3. Dewi Ratnasari,1 Djatnika Setiabudi,2 Lulu Eva Rakhmilla3. Clinical Presentation and Laboratory Features in Pediatric Typhoid Fever Patient Susceptibility to First-line Antibiotic Therapy AMJ.2015;2(4):584-90 DOI: 10.15850/amj.v2n4.653.

4. Ariati NN, Wiardani NK, Kusumajaya AAN, Supariasa IDN, Sidiartha L. Buku Saku Antropometri Gizi Anak PAUD. Inteligensia Media (Kelompok Penerbit Intrans Publishing); 2020. https://books.google.co.id/books?id=zTESEAAAQBAJ

5. Ulfa F, Handayani OWK. Kejadian Demam Tifoid di Wilayah Kerja Puskesmas Pagiyanten. HIGEIA (Journal Public Heal Res Dev. 2018;2(2):227-238. doi:10.15294/higeia.v2i2.17900

6. Alvarez M de la L, Wurgaft F, Espinoza J, Araya M, Figueroa G. Hygiene habits and carriers in families with a child who has had typhoid fever. Rev Saude Publica. 1992;26(2):75-81. doi:10.1590/S003489101992000200003

7. Pether JVS, Scott RJD. Salmonella carriers; are they dangerous? A study to identify finger contamination with Salmonellae by convalescent carriers. J Infect. 1982;5(1):81-88. doi:10.1016/S0163-4453(82)93365-5

8. Setiabudi D, Madiapermana K. Demam Tifoid pada Anak Usia di bawah 5 Tahun di Bagian IImu Kesehatan Anak RS Hasan Sadikin, Bandung. Sari Pediatr. 2016;7(1):9-14.

9. Pramitasari OP. Faktor risiko kejadian penyakit demam tifoid pada penderita yang dirawat di rumah sakit umum daerah ungaran. J Kesehat Masy Univ Diponegoro. 2013;2(1):18787.

10. Ramaningrum G, Anggraheny HD, Putri TP. Faktor-faktor yang Mempengaruhi Kejadian Demam Tifoid pada Anak di RSUD Tugurejo Semarang. J Kedokt Muhammadiyah. 2017;5(2).

11. NP Rembulan Ayu. Indeks RDW dan Mentzer sebagai Uji Skrining Diagnosis Thalassemia. J Major. 2015;4(7):7-12.

12. Lestari R, Arguni E. Profil Klinis Anak dengan Demam Tifoid di Rumah Sakit Umum Pusat Dr Sardjito Yogyakarta. Sari Pediatr. 2017;19(3):139-144.

13. Rosche KL, Aljasham AT, Kipfer JN, Piatkowski BT, Konjufca V. Infection with Salmonella enterica Serovar Typhimurium Leads to Increased Proportions of F4/80+ Red Pulp Macrophages and Decreased Proportions of B and T Lymphocytes in the Spleen. Moser M, ed. PLoS One. 2015;10(6):e0130092. doi:10.1371/journal.pone.0130092

14. Srai SK, Sharp P. Proteins of Iron Homeostasis. In: Iron Physiology and Pathophysiology in Humans. Humana Press; 2012:3-25. doi:10.1007/978-1-60327-485-2_1

15. Yildirim I, Ceyhan M, Bayrakci B, Uysal M, Kuskonmaz B, Ozaltin F. A Case Report of Thrombocytopenia-associated Multiple Organ Failure Secondary to Salmonella enterica Serotype Typhi Infection in a Pediatric Patient: Successful Treatment With Plasma Exchange. Ther Apher Dial. 2010;14(2):226-229. doi:10.1111/j.1744-9987.2009.00714.x

16. Qamar U, Aijaz J. Haematological changes associated with typhoid fever. Rawal Med J. 2013;38(1):32-35.

17. NAFIAH F, KHOIRIYAH RA, MUNIR M. DIAGNOSA DEMAM TIFOID DISERTAI KONDISI KADAR LEUKOSIT PASIEN DI RUMAH SAKIT ISLAM SAKINAH MOJOKERTO. KLOROFIL J IImu Biol dan 
Terap. 2017;1(1). DOI: http://dx.doi.org/10.30821/kfl:jibt.v1i1.1231

18. Ishaq U, Malik J, Asif M, et al. Eosinopenia in Patients With Typhoid Fever: A Case-Control Study. Cureus. 2020;12(9). doi:10.7759/cureus.10359

19. Dale, D.C. (2015). Neutropenia. In eLS, John Wiley \& Sons, Ltd (Ed.). https://doi.org/10.1002/9780470015902.a0002179.pub3.

20. George B. Segel, MD,* Jill S. Halterman, MD, MPH†. Neutropenia in Pediatric Practice. Pediatrics in Review Vol.29 No.1 January 2008.

21. Uplaonkar S V, Kauser SH, Tengli MB. Haematological profile in typhoid fever. Indian J Pathol Oncol. 2017;4(2):263-265. doi:10.18231/2394-6792.2017.0054

22. Qamar U. Hematological changes associated with typhoid fever Children's Hospital and Institute of Child's Healt. Rawal Med J. 2013;38(1):32-35.

23. Ifeanyi 0 . Changes in some haematological parameters in typhoid patients attending University Health Services Department of Michael Okpara University of Agriculture, Nigeria. InjJCurrMicrobiolAppSci. 2014;3(1):670-674.

24. Dutta P, Nahrendorf M. Regulation and consequences of monocytosis. Immunol Rev. 2014;262(1):167-178. doi:10.1111/imr.12219

25. AHMAD N, CHATTHA MN, NAYYAR ZA. Frequency of Thrombocytopenia in Children with Enteric Fever at PAF Hospital Sargodha. PJMHS. 2020;14(JAN MAR):632-633. 